\title{
Virusinfeksjon kan gi autoimmun tyreoiditt
}

Virusinfeksjon kan ha betydning for utvikling av autoimmune tyreoiditter, viser funn fra Sara Salehi Hammerstads doktorgrad.

Autoimmune tyreoiditter består hovedsakelig av Graves sykdom og Hashimotos tyreoiditt og er blant de hyppigste stoffskifte- og autoimmune sykdommer. Årsaken til sykdommene er ikke kjent, men antas å være en kombinasjon av predisponerende gener og miljøfaktorer som kan utløse en autoimmun reaksjon.

- I mitt doktorgradsarbeid har jeg påvist virus i thyreoideavev fra tidlig stadium av autoimmune tyreoiditter. I vev fra pasienter med Graves sykdom ble enterovirus-RNA og viruskapsidprotein 1 oftere påvist enn $\mathrm{i}$ vev fra kontrollgruppen. Ved Hashimotos tyreoiditt fant vi betydelig destruksjon av vevet og uttalt betennelse. Dette viser at sykdomsprosessen har startet mye tidligere enn på det tidspunktet tilstanden ble oppdaget, sier Hammerstad.

- Vi har også undersøkt ekspresjonen av myksovirus-resistansprotein A (MxA), en sur- rogatmarkør for lokal produksjon av interferonsom respons på virusinfeksjon. Antall MxA-positive celler og ekspresjon av MxA i epitelceller og endotelceller var økt $i$ alle stadier i Hashimotos tyreoiditt og tidlig i forløpet av Graves sykdom. Dette kan være et indirekte tegn på virusinfeksjon.

- Tidligere studier har basert seg på funn fra blodprøver hos pasienter med mangeårig sykdom og som var under behandling. Funn fra vev i tidlig stadium av tyreoiditten bidrar til en bedre forståelse av mekanismene bak sykdommen. Hvis virus er en utløsende faktor for sykdommen, er det mulig å forebygge med vaksiner eller behandle med antivirale medisiner før vevet og hormonproduksjonen blir ødelagt.

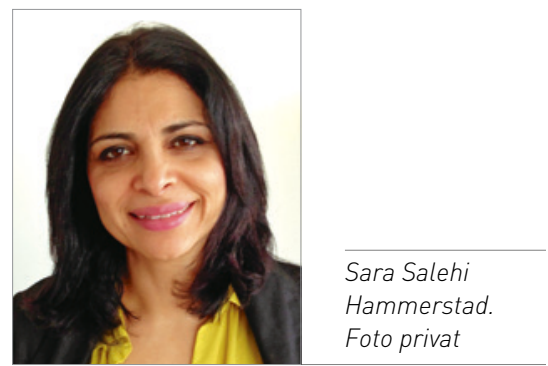

Hanne Støre Valeur

hanne.store.valeur@legeforeningen.no

Tidsskriftet

\section{Bildediagnostikk i plastikkirurgi}

\section{Varmekamera kan erstatte CT i planleggingen av brystrekonstruksjon med kroppseget vev fra abdomen.}

Hvert år rammes mer enn 2500 norske kvinner av brystkreft, og mange må fjerne brystet. Nytt bryst kan konstrueres av hud og fett fra abdomen, men slik kirurgi kan være risikofylt. For å unngå komplikasjoner må kirurgen ha oversikt over de små perforatorarteriene i bukveggen. I dag brukes CT-angiografi rutinemessig for å kartlegge disse arteriene, men undersøkelsen medfører at pasienten utsettes for kontrastmidler og ioniserende stråling.

I sitt doktorgradsarbeid har Sven Weum gjennomført én eksperimentell og to kliniske studier der dynamisk infrarød termografi (DIRT) ble sammenliknet med indocyaningrønn fluorescens-angiografi, håndholdt doppler og CT-angiografi. Dynamisk infrarød termografi er en ikke-invasiv metode der hudens overflatetemperatur brukes til å kartlegge blodperfusjon.

- Studiene viser at dette er en pålitelig metode for preoperativ kartlegging av per- foratorarterier. Undersøkelsen er enkel, resultatene er enkle å tolke og den er uten risiko for pasienten, sier Weum.

Weum har også gjennomført en klinisk studie der han har undersøkt anatomiske silikonprotesers form og oppførsel etter operasjonen. Ved MR-undersøkelse ble protesenes dimensjoner i rygg- og mageleie kartlagt. - Resultatene viser at protesene har anatomisk form, samtidig som de er myke nok til å forandre dimensjoner når kroppens stilling forandres. Denne kunnskapen gjør det lettere å forutsi det postoperative resultatet og kan bidra til mer objektiv diagnostikk av kapselkontraktur ved hjelp av MR, sier Weum.

\section{Hanne Støre Valeur}

hanne.store.valeur@legeforeningen.no

Tidsskriftet

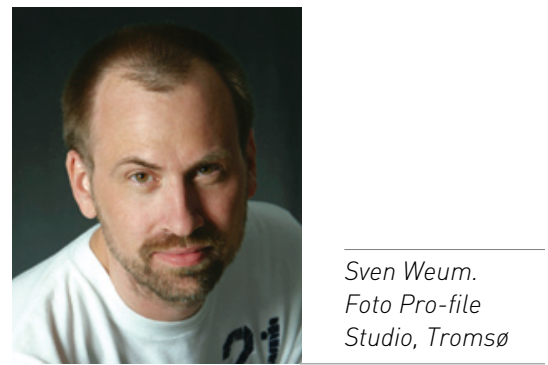

Disputas

Sven Weum disputerte for ph.d.-graden ved Universitetet i Tromsø 29.4. 2013. Tittelen på avhandlingen er Imaging in plastic surgery. A clinical and experimental study with notes on the history of medical imaging. 